\title{
PAINTING WITH WORDS: DESCRIBING WOMEN IN PHOTOGRAPHY
}

\author{
PINTANDO CON PALABRAS: LA DESCRIPCIÓN \\ DE MUJERES EN LA FOTOGRAFÍA
}

\author{
Authors / Autoras: \\ Iryna Mykytka \\ Universidad Católica de Murcia \\ Murcia, Spain \\ imykytka@ucam.edu \\ https://orcid.org/0000-0001-7228-9841 \\ Isabel Balteiro \\ Universidad de Alicante \\ Alicante, Spain \\ balteiro@ua.es \\ https://orcid.org/0000-0002-9771-5883
}

\section{Submitted / Recibido: 05/11/2020 \\ Accepted / Aceptado: 22/03/2021 \\ To cite this article / Para citar este artículo: Mykytka, I., \& Balteiro, I. (2021). \\ Painting with words: describing women in photography. Feminismo/s, 38, 149-175. Women, Sexual Identity and Language [Monographic dossier]. I. Balteiro (Coord.). https://doi.org/10.14198/fem.2021.38.06 \\ Licence / Licencia: \\ This work is licensed under a Creative Commons Attribution 4.0 International. \\ (c) (i)}

(C) Iryna Mykytka \& Isabel Balteiro

\section{Iryna MYKYTKA \& Isabel BALTEIRO}


Keywords: Women/female; Men/male; Gender; Digital photography; Descriptive adjectives.

\section{Resumen}

Este estudio pretende identificar y analizar los recursos lingüísticos que se utilizan para describir a las mujeres en la fotografía, y las similitudes y diferencias entre las descripciones de mujeres y hombres. Hoy en día, las fotografías digitales suelen ir acompañadas de texto, tales como títulos, descripciones, comentarios o etiquetas. Aunque el lenguaje utilizado en las redes sociales se ha explorado en gran medida en relación con diferentes campos de conocimiento y desde diferentes perspectivas, hasta donde sabemos, no hay ningún trabajo que trate el lenguaje utilizado por los fotógrafos profesionales para describir a mujeres y hombres. Para llevar a cabo este estudio, hemos recopilado dos muestras de las palabras clave utilizadas por fotógrafos profesionales para describir imágenes que representan figuras femeninas y masculinas, extraídas de un banco de imágenes de fotógrafos profesionales (Alamy). Para cumplir con el objetivo propuesto, se han identificado y seleccionado los adjetivos descriptivos utilizados, para luego analizarlos, compararlos y contrastarlos. Los resultados muestran grandes similitudes en el uso de los adjetivos descriptivos para las imágenes de mujeres y hombres. Asimismo, parecen sugerir que las mujeres y su belleza son descritas desde la perspectiva masculina y los estereotipos presentes en nuestra sociedad.

Palabras clave: mujeres/femenino; hombres/masculino; género; fotografía digital; adjetivos descriptivos.

\section{INTRODUCTION}

Since its beginnings in the first half of the nineteenth century, together with other artistic fields, photography has been dominated by men (Carro Fernández, 2010). Men, who historically objectified women and denied female subjectivity (Gabbard, 1998), were in charge of creating and disseminating the image of women in our society. The female figure, therefore, was the passive protagonist of art history (Pérez Gauli, 2000) and the role of women in photography was reduced for a long time to objects to be photographed (Muñoz-Muñoz \& González-Moreno, 2014). This relates to the theory of the «male gaze» (see Berger, 1972; Mulvey, 1989) in visual arts: women are assigned the passive status of being looked at, whereas men are the active subjects who look (Mulvey, 1989). Women in photography are thus

Feminismo/s 38, July 2021, 149-175 
viewed and represented from the dominant «masculine» point of view, as the viewer is situated in a «masculine» position.

Manuals on photographing women, written mainly by men focus on posing (e.g. Perkins, 2009; Siegel, 2012) or editing (e.g. Ames, 2004, 2006; Rojas, 2016). They teach how to smooth skin, sculpture bodies, remove blemishes, and other retouching techniques «making photographs of women look better than their best» (Ames, 2004). Consequently, ideals of women's physical appearance are to a great extent created by photographs (Sontag, 1999, p. 1). Yet, photography not only shapes reality but also reflects it (see Pultz, 1995, p. 7). Döring et al. (2016) found that Instagram users not only reflect traditional gender stereotypes in their photographs, but are even more stereotypical than magazine adverts, which are considered to be highly stereotypical.

A good number of studies in photography have already considered the gender perspective. Most of them focus on gender inequality and aim at shedding light on different female photographers. On the one hand, Benjamin (1931), Berger (1972), Mitchell (1979), Gover (1988), Raymond (2017), or Newbury et al. (2020), amongst others, highlight leading women in the field of photography throughout history and around the world, while Rosenblum (2015) provides a history of women photographers. On the other hand, González-Moreno (2017) and Marín and Ganzabal (2011) study the construction of women's identity through photography, whereas other works have focused on women's visual representations in photography in different historical periods and countries (Doy, 1998; Fahmy, 2004; Otto \& Rocco, 2011). Numerous studies also focus on the effect of photographs on the self-esteem and body satisfaction of women (Betz et al., 2019; Coy-Dibley, 2016; Grogan, 2017; Ruggerone, 2006). As Bordo (2003) notes, with images digital modification, women are being 'educated' to shift their perception of what a normal woman's body looks like, wanting their bodies to match an unrealistic, polished, slimmed and smoothed ideal.

This article analyzes the representation of women in digital photography from a linguistic perspective, by exploring the linguistic devices used in their descriptions. More precisely, two main questions are here addressed: (1) how women are described in photography captions, and (2) how similar are these descriptions of women and men. 


\section{WOMEN AND PHOTOGRAPHY: A BRIEF HISTORICAL OVERVIEW}

The origin of photography has been attributed to a number of male inventors. References to women inventors and mentions to women are not frequent when talking about photography (or art) in the 19th century. Still, some references may be found, increasing through the 20th century: Julia Margaret Cameron, one of the inescapable classics to understand the history of photography, its invention and development in the 19th century, and the source of inspiration of pictorialist photography, appeared in Benjamin (1931) as a consecrated photographer, side by side with other pioneering photographers.

In an attempt to rewrite the history of photography and add a female perspective, recent feminist researchers like Denny (2009, 2010, 2012), González-Moreno (2017), Muñoz-Muñoz and González-Moreno (2014, 2017), Rosenblum (2015), Rosler $(2004,2012)$ have shed light on other female figures in this field. For example, Constance Talbot, William Fox Talbot's wife, is said to have participated in her husband's experiments, which gave way to photography (Muñoz-Muñoz \& González-Moreno, 2014, p. 41); or Anna Atkins, considered the first female photographer, who made cyanotypes (early photographic process) of sea algae and published what is considered the first book photographically illustrated (Denny, 2009, p. 803). Thanks to feminist research(ers), lists of female photographers who have contributed to this field have started to emerge. However, the number is still far from equal to men. As Nochlin (1971/2018) concluded, due to women's obligations in domestic roles, they have not had space and time to become great artists. Even if women tried to participate in photography, works of female authorship were commonly signed by their relatives of the male gender in order to be published or exhibited (as in Deepwell, 1991; Guerrilla Girls, 2020; Robinson, 1987; Walsh, 1994; Wolff, 1990, 1994).

In the 19th century, photography was practically inaccessible to women and the appearance of women with cameras was rare (Gover, 1988, p. 5), due to society constraints. At the turn of the 20th century, with the introduction of the compact camera developed by Kodak in 1888, women turned to photography either professionally or as a hobby (Gover, 1988, p. 2). Women were seen as potential customers and advertisements addressed them directly, combining a dual emphasis on the small size of the camera and the simplicity 
of the process of taking photographs as if women were not able to engage in photography with more complex equipment. Kodak's slogan was «You push the button, we do the rest». As pointed out by Riches (2014) the «combination of reduced size and a streamlined process -one so simple even a woman could do it- was central to George Eastman's decision to use a female figure as the central motif in his aggressive marketing campaign» (p. 6). This coincided with the first-wave feminism, which also had an effect on the growing presence of women in photography, who, nonetheless, were still to some extent, according to Gover $(1998$, p. 2), in a field created by and for men.

It was after the second-wave feminism, when women rebelled through photography and began to use it as a tool against gender inequalities, trying to dismantle the roles assigned to women by patriarchal society (MuñozMuñoz \& González-Moreno, 2017, p. 210; 2014, p. 40). Women started to claim the right to construct their own identity and representations using a camera and a female body as a space for creativity and criticism, often creating the most radical photographs (Broude \& Garrad, 1996). Valie Export (1969), for example, shows a photograph of a woman (herself) wearing jeans and exposing the genitals with a cutout triangle in the pubic area -which is still groundbreaking fifty years later. Photography, as noted by Spence and Solomon (1995), is an empowering vehicle for female identity.

In the 1960s and 70s, female photographers attempted to create a more real and more authentic picture of women: Eve Arnold (1976/2020) questioned the imprisonment of women in stereotype roles, while Abigail Heyman (1974/2020) showed unknown women and celebrities in unexpected moments of their daily lives, without any retouching and so offering a vision of women far from the glamour of glossy magazines. Susan Meiselas (1976/2020) investigated into striptease sideshows giving a voice to their subjects, depicting their work, dreams, and ambitions. Many were devoted to creating alternative representations of women and the presence of women in photography started to grow significantly. This seems to have continued during the third-wave feminism, which began in the 1990s: Park $\&$ Ha (2015) analyzed fashion photographs from that period and found that they express liberation and rights of women or sexual freedom, independent women as subjects of power, challenging and threatening male power. They also define multicultural female images, reducing a gap among coloured

Feminismo/s 38, July 2021, 149-175 
races and other cultures and escaping from the dual oppression, besides queer female images, aiming at diverse gender identities. To give an example, photographs entitled or whose themes are «Grande stile» or «Shy, Hush» overturn passive female images, breaking up a dichotomy between virtuous women and decadent women, and aim for female rights, freedom from sexual oppression, initiative, and autonomy. This is inferred from present external expression characteristics concerning appearance and garments; location, gesture and posture (the male is the background, the woman leans on the chair and her legs open); and the gaze is staring at the front.

The fourth wave continues to challenge sexism and is characterized by its diversity of purpose and its reliance on the internet (Munro, 2013, p. 22). An example in fashion photography is Girlgaze (https://girlgaze.com; see Looft, 2017), a platform launched in 2016 by the British photographer Amanda de Cadenet, aiming to reduce gender inequalities in the field of photography by promoting talented female photographers and the way they see women, but mainly «emerging womxn and non-binary creative talent with the world's best companies». Its history began with a hashtag on Instagram (\#girlgaze) and evolved into a movement (de Cadenet, 2017). Today, the Instagram page \#GirlGaze publishes daily new photographs taken by women and represents women from the female perspective (see Zafra 2005, 2013).

Despite the fact that the movement for women's equality is gaining momentum and currently we are witnessing a steady rise in women's presence and success in different genres of photography (Sattari $\&$ Mousavi, 2013, p. 74), the struggle for gender equality in this field is far from fully achieving its purpose (see, Muñoz-Muñoz \& González Moreno, 2017; SebagMontefiore, 2019). Studies show that the number of female photographers is still considerably smaller compared to male photographers nowadays. Whitley and Kalof (2020) found that only 16\% of elite wildlife photographers are women, and Muñoz-Muñoz and González Moreno (2017) note that female photographers are highly underrepresented in European museums (less than $1 \%$ in some of them). Jill Greenberg, a celebrated photographer, revealed in a TEDx Talk that in the US, 92\% of adverts and $85 \%$ of magazine covers are shot by men (2018). Similarly, Hadland et al. (2016) confirm that photography is a «heavily male-oriented» profession with $85 \%$ of male respondents. Therefore, women remain being disregarded and photography 
still seems to be a male-dominated medium. This affects what is seen in magazines, newspapers, on TV, or billboards, and, consequently, how the image of women is perceived.

\section{THE DEPICTION OF WOMEN IN PHOTOGRAPHY}

Despite the gap in literature regarding the linguistic descriptions of women in photography, considerable research has been done on the visual depictions of female figures in this field. It appears that gender inequality in photography continues to affect women's representation. Due to the reduced number of women photographers, on the one hand, men continue to decide how women should be depicted. On the other, women enter a cultural structure and achieve success by adopting a non-critical perspective, reproducing the stereotypes of the male gaze. The male gaze has become deeply ingrained in our society (Vitova, 2019). Thus, women tend to be «portrayed in ways that are deemed to be attractive to a male spectator, although most of the actual audience is likely to be women» (Ruggerone, 2006, p. 356).

Sontag (1999) points out that «nobody looks through a book of pictures of women without noticing whether the women are attractive or not. To be feminine [...] is to be attractive, or to do one's best to be attractive; to attract». Furthermore, «women are judged by their appearance as men are not, and women are punished more than men are by the changes brought about by aging» (p. 1). Sontag (1984) argues that men in our culture have an advantage of having two standards of beauty -the boy's and the man's, while only one standard of female beauty exists- the girl's:

The beauty of a boy resembles the beauty of a girl. In both sexes, it is a fragile kind of beauty and flourishes naturally only in the early part of the life-cycle. Happily, men are able to accept themselves under another standard of good looks -heavier, rougher, more thickly built. A man does not grieve when he loses the smooth, unlined, hairless skin of a boy. For he has only exchanged one form of attractiveness for another [...] There is no equivalent of this second standard for women. The single standard of beauty for women dictates that they must go on having clear skin. Every wrinkle, every line, every grey hair, is a defeat. (p. 107)

Sontag (1999) notes that the «ideals of appearance such as youthfulness and slimness are in large part now created and enforced by photographic images» 
(p. 1). Studies of the portrayal of the female body in advertising photography have found that models became thinner and thinner between the 1960s and the 1990s (see Sypeck et al., 2004). Although it was widely suggested that magazines and newspapers needed to review their practices, they continued through the 2000s and seem to be still present (Grogan, 2017, pp. 23-24).

The male gaze and stereotypes are still highly present in social media. Döring et al. (2016) have found that selfies by young females show the visual codes of subordination defined by Goffman (1979) and Kang (1997) such as feminine touch, lying posture, imbalance, withdrawing gaze, loss of control, and body display. Additionally, they found that young females' selfies more often imply seduction (e.g. kissing pout), while young males' selfies more often contain muscle presentation (implying strength) (Döring et al., 2016). Related to the idea of withdrawing gaze, Goffman (1979, p. 64) explains that when an individual withdraws the gaze from the scene he or she is going «away» and female models are often portrayed as mentally absent, putting emphasis on their body instead.

Other works on the visual depiction of women in Western society reveal that «whiteness» is the symbol of femininity and beauty (Deliovsky, 2008). As Bordo (2003) pointed out, homogenized images of «whitified» feminine beauty become normalized and «function as models against which the self continually measures, judges, 'disciplines', and corrects itself» (p. 63). Nobody in this culture wants to have his or her nose reshaped to look more «African» or «Jewish», as noted by Bordo (2003, p. 64). She states that even though sometimes we do find alternative models of beauty, this is because «consumer capitalism depends on the continual production of novelty, of fresh images to stimulate desire, and it frequently drops into marginalized neighbourhoods in order to find them» (2003, p. 62). Such elements, according to Bordo (2003), «will be explicitly framed as exotica» (p. 62) and will not «be permitted to overwhelm the representation and establish a truly alternative or 'subversive' model of beauty or success» (p. 63).

Moreover, women are often depicted as victims, receivers, and helpless sufferers (Morna, 2002, p. 96), or as «'decorative add-ons' and not as serious role-players in society» (Soobben, 2013, p. 37). Jennifer Moss (2014), a former fashion photographer, studied how women are depicted in fashion magazines and created four categories: (1) woman as a victim/scared, (2) 
undressed/positioned for sex, (3) weak/submissive/non-threatening/childlike, (4) objectified/non-human/one of many. Three years later she carried out further research and added one more category -(5) strong/in charge/ happy (Moss, 2017). This might imply that the representation of women in photography in our culture might be starting to change slowly.

While research on physical appearance of women in photography abounds, emotionality and personality have not been specifically addressed. Studies on emotions and stereotypes in photography have been mainly carried out in news photography, where they seem to experience sadness, fear, and sympathy more often than men, while anger and pride are more common in men (Rodgers et al., 2007). They usually have a smile on their faces, a calm demeanour, and a submissive stance, while men have a frown on their faces and an excited demeanour (Rodgers et al., 2007, p. 132), which goes in line with the common belief that women smile more and men show more anger (see, for example, Fischer, 1993; Hall et al., 2000; LaFrance \& Hecht, 1999; Shields, 1987). Studies on the personality of women in photography mostly focus on self-representation. Haferkamp et al. (2012) suggest that women place higher priority on creating a positive self-presentation, while men are less concerned about the image they present. Dollinger and Clancy (1993) studied the gender differences in auto-photography following the Big Five -a taxonomy usually used to study the personality that categorizes traits into the broad domains of Extraversion, Agreeableness, Conscientiousness, Neuroticism, and Openness/Intellect) (see for example Digman, 1990; John et al., 2008)- and found that women scored high in Neuroticism and low in Extraversion, depicting themselves as emotionally unstable, vulnerable, insecure and introverted.

\section{OBJECTIVES AND METHODOLOGY}

This study aims at exploring how women are linguistically depicted in digital photography, by identifying, analyzing and comparing the terms (and their connotations) used by professional photographers to describe women and men. With these purposes in mind, a sample of images and accompanying text (captions) was compiled from one of the most popular image stocks of professional photographers-Alamy (https://www.alamy.com). The 
photographs and captions were selected by searching «woman» and «man» as keywords. Two similar samples, each with the first one hundred more popular images, were obtained: one with pictures and descriptions of women -Women's Sample (henceforth, WS) (5,919 tokens; 1,498 word types)- and another with men's pictures and descriptions -Men's Sample (henceforth, MS) (5,140 tokens; 1,427 word types).

Once the samples were compiled, we proceeded with the manual extraction of word types related to the description of women and men. Only words used to describe persons, specially adjectives, were considered and analyzed here. As a result, out of 1,498 word types from our sample of women's descriptions, 138 adjectives (904 tokens) were selected for the analysis. Similarly, out of 1,427 word types from our men's sample, we focused on 173 adjectives (935 tokens).

AntConc software (Anthony, 2014) was used in the data processing to generate the frequency of lexical words in the two sets of texts and the selection and classification of the adjectives were undertaken manually. Merriam Webster's dictionary (https://www.merriam-webster.com) was used in order to check if the items were adjectives.

\section{RESULTS}

The analysis of the adjectives found in the samples has revealed two major categories, namely, (1) those related to the individuals' physical features, and (2) those related to psychological characteristics. Several sub-classifications may be distinguished within each of those. As to adjectives describing physical features, five subcategories may be mentioned: adjectives describing person's age, race/ethnicity and nationality, general appearance, hair, and adjectives related to clothing. The second group is composed of adjectives describing personality and ability or state of mind, such as those indicating features corresponding to emotions and feelings (see Table 1). 
Table 1. Frequency of each (sub-)category in both samples

\begin{tabular}{|c|c|c|c|c|c|c|c|c|c|}
\hline \multirow[b]{2}{*}{ Category } & \multirow{3}{*}{ Sub-category } & \multicolumn{4}{|c|}{ Women's sample } & \multicolumn{4}{|c|}{ Men's sample } \\
\hline & & \multicolumn{2}{|c|}{ Tokens } & \multicolumn{2}{|c|}{ Types } & \multicolumn{2}{|c|}{ Tokens } & \multicolumn{2}{|c|}{ Types } \\
\hline Body & & 699 & $77 \%$ & 67 & $49 \%$ & 725 & $78 \%$ & 95 & $55 \%$ \\
\hline & Gentilics & 153 & $17 \%$ & 16 & $12 \%$ & 219 & $23 \%$ & 30 & $17 \%$ \\
\hline & Age & 295 & $32 \%$ & 16 & $12 \%$ & 281 & $30 \%$ & 18 & $10 \%$ \\
\hline & Appearance & 146 & $16 \%$ & 15 & $11 \%$ & 123 & $13 \%$ & 26 & $15 \%$ \\
\hline & Clothing & 44 & $5 \%$ & 10 & $7 \%$ & 83 & $9 \%$ & 15 & $9 \%$ \\
\hline & Hair & 61 & $7 \%$ & 10 & $7 \%$ & 19 & $2 \%$ & 6 & $4 \%$ \\
\hline \multicolumn{2}{|l|}{ Mind } & 205 & $23 \%$ & 71 & $51 \%$ & 210 & $22 \%$ & 78 & $45 \%$ \\
\hline & $\begin{array}{l}\text { Emotions \& } \\
\text { feelings }\end{array}$ & 72 & $8 \%$ & 29 & $21 \%$ & 94 & $10 \%$ & 25 & $14 \%$ \\
\hline & $\begin{array}{l}\text { Personality } \& \\
\text { ability }\end{array}$ & 125 & $14 \%$ & 38 & $27 \%$ & 112 & $12 \%$ & 51 & $30 \%$ \\
\hline & Other & 8 & $1 \%$ & 4 & $3 \%$ & 4 & $1 \%$ & 2 & $1 \%$ \\
\hline \multicolumn{2}{|l|}{ Total } & 904 & $100 \%$ & 138 & $100 \%$ & 935 & $100 \%$ & 173 & $100 \%$ \\
\hline
\end{tabular}

In general, the results seem to suggest that the most important features when describing both men and women are mainly physical rather than emotional. Thus, physical appearance, age, clothing, or ethnicity, amongst others, rather than their emotions or feelings, tend to be mentioned. Accordingly, $77 \%$ of the adjectives used (699 tokens) in the descriptions of women refer to the body and 23\% (205 tokens) to mind, and similarly, $78 \%$ (725 tokens) used in the descriptions of men refer to the body and 22\% (210 tokens) to the mind (see Table 1 above).

\subsection{Adjectives describing bodies of women and men}

\subsubsection{Age}

As shown in Table 1, the sub-group that yielded the highest number of occurrences in both samples is that of age-qualifying adjectives: 295 tokens (32\% of the total) in the WS and 281 tokens (30\% of the total) in the MS, which seems to indicate the importance given to age in both cases, although apparently it is slightly more important in women. The significance of age 
can be additionally found in the two most frequent adjectives in both samples -adult and young, which present 113 (12.5\%) and 120 (12.1\%) occurrences respectively in the WS, and $81(8.6 \%)$ and 79 (8.4\%) occurrences in the MS, also suggesting that the importance of age for women is higher than for men. Although Sontag (1984) highlights that «men, too, are prone to periodic bouts of depression about aging», she adds that «getting older is less profoundly wounding for a man» and «society is much more permissive about aging in men» who «are 'allowed' to age without penalty» in comparison to women (p. 101), as reflected in this study.

Adjectives affecting age were also divided into two subcategories, namely, «young» and «elderly», which excluded adjectives like adult, grown or grownup, which could fit in either. Thus, the analysis of the adjectives in the WS seems to suggest that women photographed are of younger ages (as adjectives such as young, juvenile, teenage, minor, teeny are highly frequent) (120 tokens; 69\%) and older women (or rather, adjectives describing their age) appear less frequently (e.g. mature, senior, elderly, older, aged, middle-aged) (55 tokens; 31\%). Unlike this, in the MS the results show a very different picture: older men are more popular in photographs (and their descriptions) than younger ones, with 106 tokens (55\%) in the case of the former and 87 tokens (45\%) in the latter. In fact the adjective senior is the sixth most common adjective in the MS occurring 33 times (3.5\% of the total) and also supporting the idea that getting older is perfectly acceptable in case of men.

\subsubsection{Race/ethnicity and nationality}

The next important subgroup is composed of the gentilics, that is, adjectives describing the ethnicity, the race, or the nationality of the subject photographed. Most of them refer to race or ethnicity and just a few describe the nationality (Italian, Canadian, German, Japanese) in the WS, where 153 tokens (17\% of the total) and only 16 word types (12\% of the total) were identified (see Table 1). Race and ethnicity, though complex categories to be further indexed, have been arranged into three groups: «white», «black/ African», and «Hispanic/Latin». The most common adjectives to describe women's race in our sample are Caucasian (52 tokens; 5.75\%), white (24 tokens; $2.6 \%$ ), and European (10 tokens; 1.1\%) which often are misused with 
the same meaning (for their misuses see for example Bhopal \& Donaldson, 1998). The percentage of $73 \%$ of tokens corresponding to these three-word types which constitute the «white» group may suggest that these are the most photographed and/or preferred women in present-day photography. The second most frequent group, although with significantly lesser results (22 tokens; 18\% within this group), is the «black/African» group. Eight percent (10 tokens) of adjectives in this group refer to the «Hispanic/Latin» group. There are a few other cases of ethnicity (e.g. Asian) which are apparently insignificant, if compared to these results. As said, this means that the majority of women from our sample are «white», and suggests that the most popular photographs in Alamy image stock show white women, which could be related to the importance of being white in order to be feminine and attractive to the (Western) dominant male gaze. Moreover, the scant presence of models of other ethnicities/races appears to support the belief that «exotica» is needed by the current consumerist society, who continuously requires novelty (Alamy's image stock is commercial).

There seems to be more diversity in the MS as there are more references to the models' origin: 30 word types (17\% of the total) and 219 tokens (23\% of the total) were located (see Table 1). Similarly, as in the WS, the most frequent tags related to the individuals' race are Caucasian (35 tokens) and white (29 tokens), which, together with European (5 tokens), constitute 43\% within this category (69 tokens); $73 \%$ in the WS. The second most popular group is «Asian» (28\%): Asian (27 tokens) and eastern (15 tokens), though this does not exist as a group in the WS. «Black/African» is in the third position with $22 \%$ (32 tokens). Finally, the «Hispanic/Latin» group presents only 4 tokens (3\%). These four groups constitute the most frequent adjectives and the main «races» identified; however, there are other adjectives that make reference to nationalities, which are more varied in the MS (e.g. Australian, Malaysian, Turkish, Portuguese, French, Mexican, Italian, Indian) than in the WS.

\subsubsection{Appearance}

The third most significant group in both samples is that of adjectives describing the models' general appearance or look. In the WS 15 adjectives (11\% of the total) constitute $16 \%$ of the total of the tokens (146 tokens), while in MS 
the variety of adjectives is higher (26 items; $15 \%$ of the total) and the number of tokens is lower (123 tokens; 13\% of the total) (see Table 1). This proves that the appearance counts more in woman's life than in a man's. Smiling is the most frequently used adjective in both samples, although slightly more frequent in the MS (39 tokens or $4.2 \%$ compared to 37 tokens or $4 \%$ ). This apparently goes against the common stereotype that women smile more, while men tend to show more anger. However, this corresponds to the focus on positive photographs that show content with potential commercial appeal.

Women's descriptions include adjectives such as beautiful (32 tokens; $3.5 \%$ ), attractive (23 tokens; $2.5 \%$ ), pretty (15 tokens; $1.7 \%$ ), cute (6 tokens; $0.6 \%$ ), or gorgeous (4 tokens; $0.4 \%$ ). Adjectives such as handsome (22 tokens; $2.3 \%$ ) and attractive (17 tokens; $1.7 \%$ ), but also ordinary and normal (1 token each; $0.1 \%$ ) are used for men, who are also described as unshaved ( 1 token; $0.1 \%$ ), fat (2 tokens; $0.2 \%$ ) or overweight ( 1 token; $0.1 \%$ ). This goes in line with the idea of a double standard of beauty in men and a single standard of beauty in women, as mentioned above. Men, therefore, exchange «the beauty of a boy» for «the beauty of a man», becoming heavier, rougher, more thickly built and accepting what nature has given to them. Women, however, «must conserve» the beauty of a girl, lacking the advantage of having the second standard of beauty. Sontag (1984) notes that «one of the norms of 'femininity' in this society is being preoccupied with one's physical appearance, so 'masculinity' means not caring very much about one's looks» (p. 105). This study seems to prove that men are allowed to be fat or overweight, whereas women must be slim and slender and follow the ideal appearance.

Women in our sample are also depicted as feminine (19 tokens; $2.1 \%$ ), cute (6 tokens; $0.6 \%$ ), angelic ( 1 token; $0.1 \%$ ), delicate ( 1 token; $0.1 \%$ ), pale ( 1 token; $0.1 \%$ ), while men appear as cool (9 tokens; 0.9\%), muscular (5 tokens; $0.5 \%$ ), strong (2 tokens; $0.2 \%$ ), muscled (1 token; 0.1 ), or rugged (1 token; $0.1 \%$ ). The former, thus, seems to be weak or non-threatening almost childlike, just like some of the women depicted in fashion magazines studied by Moss (2014), whereas men appear to follow the common stereotype of being strong.

Note that the word feminine is among the most frequent in the WS (19 tokens; $2.1 \%$ ) which highlights the importance of femininity in women's appearance. Apparently photographs of women who look feminine sell more being more appealing to the male gaze. Similarly, in the MS special attention 
should be paid to cool (9 tokens; $0.9 \%$ ) which is the fourth most common within this category, after smiling (39 tokens; 4.1\%), handsome (22 tokens; $2.3 \%$ ), and attractive (17 tokens; $1.7 \%$ ). Consequently, the results suggest that while for a woman being feminine is essential, for a man it is being cool, or being macho (the latter is also present in our sample, although only twice). Moreover, men in our sample are described as athletic (3 tokens; 0.3\%), fit (3 tokens; 0.3\%), and flexible (1 token; 0.1\%) relating them to sport, when no such references were found in the WS. As Sontag (1984, p. 105) points out, the physical ideal of both sexes is different: boys are urged to improve their bodies through sport (to become stronger), meanwhile girls are not encouraged to develop muscles; being «feminine» means being physically weak and being continually «defended».

\subsubsection{Clothing}

As illustrated in Table 1 above, in the MS the number of tokens is almost double that in the WS (83 tokens compared to 44 tokens in the WS), which is quite remarkable. The adjectives located are mainly of two types, those describing clothes style (e.g. fashionable, trendy) or clothing items themselves (e.g. sleeveless). Special attention may be paid to casual, the most frequent adjective within this category in both samples, which means that both women and men in our sample wear mostly casual clothes. Still, an important difference can be drawn from the use of this adjective: it seems to be significantly more frequent in the MS, used 50 times (5.3\%), compared to 29 tokens (3.2\%) in the WS. In fact, it is the third most frequently used adjective to describe men in our sample. This seems interesting as its use prevails considerably over adjectives related to the physical appearance, such as handsome (22 tokens; $2.3 \%$ ), which appears on the tenth position. This may support the idea that men are less concerned about clothing or their appearance than women. 


\subsubsection{Hair ${ }^{1}$}

Adjectives describing hair are particularly popular in women's descriptions (61 tokens, 7\%; 10 types, 7\%) and significantly less important when describing men (19 tokens, 2\%; 6 types, 4\%) (see Table 1). Out of 61 tokens in the WS, 53 refer to colour while 12 to hairstyle. The majority of the women included in the sample are described as blonde (28 tokens, 53\% within this category), which goes in line with one of the most common stereotypes - that blondes are an ideal of feminine beauty in our society that «gentlemen» are alleged to prefer.

Adjectives describing dark-haired women (e.g. brunette, brownhaired) appear 19 times in total (36\% within this category), while the least common are grey (4 tokens, $7 \%$ ) and redheaded (2 tokens, $4 \%$ ). The low frequency of the latter may be explained by the fact that red hair is not so common in real life. In the case of grey, its low frequency responds to the fact that most of the female models in the sample are «young», and grey hair is typical of older women, being also true that women try to mask their age by dying their hair as explained earlier.

Other adjectives within this group refer to hairstyle, such as wavy (1 token; $0.1 \%$ ), short (2 tokens; $0.2 \%$ ), and curly (5 tokens; $0.5 \%$ ). In the men's descriptions, adjectives describing colour also prevail: blonde (8 tokens; $0.8 \%$ ), fair (1 token; 0.1\%), brunette ( 2 tokens; $0.2 \%$ ); however, the second most frequent adjective after blonde is bald ( 5 tokens; $0.5 \%$ ). These results suggest that, on the one hand, hair plays a more important role in physical appearance in the description of women and, on the other, they prove once again the existence of the second standard of beauty for men-acceptance of losing hair and still looking good and being accepted by society.

\subsection{Adjectives describing the mind of women and men}

This group includes those adjectives that refer to (1) personality and ability, and (2) feelings and emotions, apart from a few cases that did not fit in any of these categories. Out of 205 tokens (23\% of the total) that make reference

1. These could have been included in the «appearance group», but due to their relatively high presence in our sample, we decided they deserve special attention.

Feminismo/s 38, July 2021, 149-175 
to women's mind, 125 (14\%) refer to personality and ability, and 72 (8\%) describe their emotions and feelings. In the case of men, 112 tokens (12\%) were used to depict their personality and ability, and 94 (10\%), their emotions and feelings. Although the total number of tokens is very similar, there seems to be a higher diversity in personality-descriptive vocabulary in the MS (51 word types compared to 38) (see Table 1).

\subsubsection{Personality and ability}

Results reveal that women in our sample are described mainly as having a positive and extroverted personality taking into account the high frequency of adjectives such as carefree (15 tokens, 1.6\%), fun (8 tokens; $0.8 \%$ ), and positive (7 tokens; $0.7 \%$ ) including other less frequent such as joyful (5 tokens; $0.5 \%$ ), light-hearted (3 tokens; $0.3 \%$ ), vivacious ( 1 token; $0.1 \%$ ), optimistic (1 token; $0.1 \%$ ), lively (1 token; $0.1 \%$ ), exuberant (1 token; $0.1 \%$ ), entertaining (1 token; $0.1 \%$ ), and funny ( 1 token; $0.1 \%$ ). Men, conversely, seem to be more reserved and introverted: adjectives such as serious (11 tokens; 1.1\%) or serene (3 tokens; 0.3\%) prevail over social (3 tokens; 0.3\%), funny (2 tokens; $0.2 \%$ ), or friendly (2 tokens; $0.2 \%$ ).

In addition, women are also described as having a calm demeanour by using adjectives such as tranquil (5 tokens; 0.5\%), calm (2 tokens; $0.2 \%$ ), peaceful (2 tokens; $0.2 \%$ ). Men are similarly depicted as calm (4 tokens; $0.4 \%$ ) or tranquil ( 2 tokens; $0.2 \%$ ), but contrary to women they can be also mad (1 token; $0.1 \%$ ) and crazy (1 token; $0.1 \%$ ). Moreover, men were described as unfaithful (1 token; 0.1\%), disloyal (1token; 0.1\%), and flirtatious (1 token; $0.1 \%$ ), which follows the idea that society is more tolerant of men's infidelity than women's. Men were found to be more agreeable than women and showing altruism more often, which can be observed through the presence of the following adjectives in the MS: agreeable (1 token; $0.1 \%$ ), believable ( 1 token; $0.1 \%$ ), caring ( 1 token; $0.1 \%$ ), comforting ( 1 token; $0.1 \%$ ), kind ( 1 token; $0.1 \%$ ), nice ( 1 token; $0.1 \%$ ), pleasant ( 1 token; $0.1 \%$ ), reassuring ( 1 token; $0.1 \%$ ). The latter seems to run against the idea that women are usually more nurturing or tender-hearted (see for example Feingold, 1994; Costa et al., 2001). 


\subsubsection{Feelings and emotions}

As shown in Table 1, in the MS 25 types (94 tokens) of adjectives qualifying feelings and emotions were found, while the WS contains 29 types (72 tokens). These adjectives have been classified following the list of emotions described first in Shaver et al. (1987) and later in Parrott (2001), who have delimited six main groups, namely, love, joy, sadness, surprise, anger, and fear. The results show that the most common emotion among women in our sample is sadness (35 tokens; $49 \%$ within this group); adjectives such as lonesome ( 5 tokens; $0.5 \%$ ), depressed ( 3 tokens; $0.3 \%$ ), lonely ( 3 tokens; $0.3 \%$ ), moody (3 tokens; 0.3\%), sad (1 token; 0.3\%), unhappy ( 2 tokens; $0.2 \%)$, nostalgic (1 token; $0.1 \%$ ), preoccupied ( 2 tokens; $0.2 \%$ ), pensive ( 3 tokens; $0.3 \%$ ), remorseful (1 token; 0.1\%), prevail in the descriptions of the emotions in women. This supports the idea that women are often depicted as victims or sufferers. Similarly, they seem to follow the withdrawal visual code or gaze of subordination defined by Goffman (1979) and Kang (1997): by withdrawing the gaze women appear mentally absent, putting the emphasis exclusively on the body. Adjectives such as absent-minded (3 tokens; 0.3\%), wandering (1 token; 0.3\%), moony (3 tokens; 0.3\%), faraway (3 tokens; $0.3 \%$ ) support this idea.

The next group, close to sadness, is that of joy (32 tokens; 44\% within this group), where half of the tokens (17 tokens) belong to happy. Other adjectives do not fit into any of the emotions (5 tokens; 7\%) probably because they seem to be feelings rather than emotions; these are relaxed, tired, and sleepy. In the case of men, the panorama is different. Contrary to women, in men the most common emotion seems to be joy (64 tokens; $68 \%$ within this group), e.g. happy, cheerful, glad, pleased, content, joyful are among the most frequent adjectives. Adjectives related to sadness are also found, although to a considerably lesser extent (10 tokens; $11 \%$ within this group). Other less common categories are surprise (surprised), fear (stressed), and anger (angry, upset), which are not found in the WS. The latter is particularly interesting, as typically anger is attributed to men (see, for example, Hess et al., 2005).

Finally, there are a few cases that do not fit in any of the two aforementioned main categories ( $1 \%$ in both samples). In the WS they are ponderous ( 3 tokens), fanciful (3 tokens), innocent (1 token), guiltless (1 token), suggesting 
the «childlike naive innocence of women», mentioned in section 3, and «dreamy and carefree nature». In the MS, macho (2 tokens) and sweet (2 tokens), two opposed poles which suggest that men can be both (although not at the same time).

\section{CONCLUSIONS}

This study is mainly linguistic in nature, as it focuses on the adjectives used by professional photographers to describe their photographs of female and male models. The results show that most adjectives in both samples describe the individuals' body: 77\% (699 items) in the women's sample and $78 \%$ (725 items) in the men's sample, while the remaining 23\% (205 items) and 22\% (210 items) were used to refer to the models' mind, i.e. personality, emotions, etc., respectively. With regard to the sub-categories, the sub-group that yielded the highest results in the WS is that corresponding to their age, with 295 tokens (32\%), followed by adjectives indicating gentilics or demonyms (153 tokens; 17\%), adjectives describing general appearance (146 tokens; 16\%) and those of personality and ability (125 tokens; 14\%). Less relevant sub-groups were those that were made up of adjectives referring to emotions and feelings (72 tokens; 8\%), the women's hair (61 tokens; $7 \%$ ) and clothing (44 tokens; $5 \%$ ). These results are very similar to those obtained from the men's sample: the most frequent adjectives used to describe men were also those alluding to their age (281 tokens; 30\%), followed by gentilics, which were slightly more common in men (219 tokens; $23 \%$ ), then by general appearance (123 tokens; 13\%), personality and ability (112 tokens; 12\%), emotions and feelings (94 tokens; 10\%), clothing (83 tokens; 9\%), and finally hair (19 tokens; 2\%), being considerably less important in men. Additionally, it has been confirmed that gender and social stereotypes are a general occurrence in present-day photography and women are mainly depicted from the male perspective. For instance, we found that white young women prevail in photography while men of older ages and other ethnicities are present to a greater extent. Also, women were more often depicted as sad and nostalgic, while men were found to be more joyful. Likewise, attractiveness and beauty seem to play a considerably more important role in the depictions of women compared to men, who are «allowed» to be fat or bald. 
This study attempts to make a contribution to the field of the language of photography, on the one hand, and to gender studies or women's studies, on the other. The importance of photography should not be ignored, basically for its omnipresence in our society: advertising, social media, or politics make use of it. Similarly, gender studies is a well-established but still growing field which is gaining importance in our developing and changing society, where studies reflect, examine, criticize or question issues related to mainly sexual identities, gender discrimination and attitudes.

We are conscious of the limitations of this study: on the one hand, the results are based on a limited sample which may not fully capture the variety of descriptions and, on the other, they are based on the most popular photographs, which may not show the complete panorama. This could be remedied by using wider corpora and by considering other sources. We encourage researchers to continue studying gender differences in photography, which still remains unexplored in many sub-areas.

\section{REFERENCES}

Ames, K. (2004). Adobe Photoshop CS: the art of photographing women. Hungry Minds Inc.

Ames, K. (2006). Adobe Photoshop CS2: the art of photographing women. John Wiley \& Sons Ltd.

Anthony, L. (2014). AntConc (Version 3.5.8) [Computer Software]. Retrieved August 15, 2020, from https://www.laurenceanthony.net

Arnold, E. (2020). The unretouched woman. In E. Arnold, A. Heyman, S. Meiselas, \& C. Bouveresse (Eds.), Unretouched women: Eve Arnold, Abigail Heyman, Susan Meiselas. Femmes à l'oeuvre, femmes à l'épreuve de l'image (pp. 23-40). Actes Sud. (Original work published in 1976).

Benjamin, W. (1931). A short history of photography. In W. Benjamin (auth.), Selected writings, (Vol. 2), (pp. 1927-1934). Retrieved March 10, 2021, from https://monoskop.org/images/7/79/Benjamin_Walter_1931_1972_A_Short_ History_of_Photography.pdf

Berger, J. (1972). Ways of seeing. British Broadcasting Corporation \& Penguin Books. 
Betz, D. E., Sabik, N. J., \& Ramsey, L. R. (2019). Ideal comparisons: body ideals harm women's body image through social comparison. Body Image, 29, 100109. https://doi.org/10.1016/j.bodyim.2019.03.004

Bhopal, R., \& Donaldson, L. (1998). White, European, Western, Caucasian, or what? Inappropriate labeling in research on race, ethnicity, and health. American Journal of Public Health, 88(9), 1303-1307. https://doi.org/10.2105/ AJPH.88.9.1303

Biesenbach, K. (ed.) (2010). Marina Abramović: the artist is present, Exhibition Catalog with essays by Klaus Biesenbach, Arthur C. Danto, Chrissie Iles, Nancy Spector, y Jovana Stokić, Museum of Modern Art.

Bordo, S. (2003). Unbearable weight: feminism, Western culture, and the body. University of California Press. https://doi.org/10.1525/9780520930711

Broude, N., \& Garrard, M. D. (1996). The power of feminist art: the American movement of the 1970s, history and impact. Harry N. Abrams. https://doi. org/10.2307/431689

Carro Fernández, S. (2010). Mujeres de ojos rojos. Del arte feminista al arte femenino. Trea.

Costa, P. T. J., Terracciano, A., \& McCrae, R. R. (2001). Gender differences in personality traits across cultures: robust and surprising findings. Journal of Personality and Social Psychology, 81(2), 322-331. https://doi. org/10.1037/0022-3514.81.2.322

Coy-Dibley, I. (2016). «Digitized dysmorphia» of the female body: the re/disfigurement of the image. Palgrave Communications, 2(1), 1-9. https://doi. org/10.1057/palcomms.2016.40

De Cadenet, A. (2017). \#girlgaze: how girls see the world. Rizzoli International Publication.

Dean, J., \& Aune, K. (2015). Feminism resurgent? Mapping contemporary feminist activisms in Europe. Social Movement Studies, 14(4), 375-395. https:// doi.org/10.1080/14742837.2015.1077112

Deepwell, K. (1991). Women artists working in Britain between the two World Wars. Birkbeck College.

Deliovsky, K. (2008). Normative white femininity: race, gender and the politics of beauty. Atlantis: Critical Studies in Gender, Culture \& Social Justice, 33(1), 49-59. 
Denny, M. (2009). Royals, royalties and remuneration: American and British women photographers in the Victorian era. Women's History Review, 18(5), 801-818. https://doi.org/10.1080/09612020903282183

Denny, M. (2010). From commerce to art: American women photographers 18501900 [Unpublished doctoral dissertation]. University of Illinois at Chicago.

Denny, M. (2012). Catharine Weed Barnes Ward: advocate for Victorian women Photographers. History of Photography, 36(2), 156-171. https://doi.org/10.10 80/03087298.2012.654938

Digman, J. M. (1990). Personality structure: emergence of the five-factor model. Annual review of psychology, 41(1), 417-440. https://doi.org/10.1146/annurev. ps.41.020190.002221

Dollinger, S. J., \& Clancy, S. M. (1993). Identity, self, and personality: II. Glimpses through the autophotographic eye. Journal of Personality and Social Psychology, 64(6), 1064-1071. https://doi.org/10.1037/0022-3514.64.6.1064

Döring, N., Reif, A., \& Poeschl, S. (2016). How gender-stereotypical are selfies? A content analysis and comparison with magazine adverts. Computers in Human Behavior, 55, 955-962. https://doi.org/10.1016/j.chb.2015.10.001

Doy, G. (1998). More than meets the eye... representations of black women in mid-19th-century French photography. Women's Studies International Forum, 21(3), 305-319. https://doi.org/10.1016/S0277-5395(98)00020-X

Export, V. (1969). Action Pants: Genital Panic [photograph]. Tate Galery. Retrieved September 20, 2020, from https://www.tate.org.uk/art/artworks/ export-action-pants-genital-panic-p79233

Fahmy, S. (2004). Picturing Afghan women: a content analysis of AP wire photographs during the Taliban regime and after the fall of the Taliban regime. Gazette, 66(2), 91-112. https://doi.org/10.1177/0016549204041472

Feingold, A. (1994). Gender differences in personality: a meta-analysis. Psychological Bulletin, 116, 429-456. https://doi.org/10.1037/0033-2909.116.3.429

Fischer, A. (1993). Sex differences in emotionality: fact or stereotype? Feminism and Psychology, 3, 303-318. https://doi.org/10.1177/0959353593033002

Gabbard, G. O. (1998). Vertigo: female objectification, male desire, and object loss. Psychoanalytic Inquiry, 18(2), 161-167. https://doi. org/10.1080/07351699809534181

Gerhard, J. F. (2013). The Dinner Party. Judy Chicago and the power of popular feminism. 1970-2007. University of Georgia Press.

Goffman, E. (1979). Gender advertisements. Harper and Row. 
González-Moreno, M. B. (2017). Fotografía, mujer e identidad: imágenes femeninas en la fotografía desde finales de los 60 [Unpublished doctoral dissertation]. University of Granada.

Gover, C. J. (1988). The positive image: women photographers in turn-of-the-century America. State University of New York.

Greenberg,J. (2018). Thefemalelens. [TEDx Talk]. RetrievedSeptember25, 2020, from https://www.ted.com/talks/jill_greenberg_the_female_lens_jan_2_2018

Grogan, S. (2017). Body image. Understanding body dissatisfaction in men, women and children (3rd ed.). Routledge.

Guerrilla Girls, The. (2020). The Guerrilla Girls. The art of behaving badly. Chronicle Books.

Hadland, A., Lambert, P., \& Barnett, C. (2016). The state of news photography 2016. Retrieved September 25, 2020, from https://dspace.stir.ac.uk/ handle/1893/24525\#.YHqW0COlNO1

Haferkamp, N., Eimler, S. C., Papadakis, A. M., \& Kruck, J. V. (2012). Men are from Mars, women are from Venus? Examining gender differences in self-presentation on social networking sites. Cyberpsychology, Behavior, and Social Networking, 15(2), 91-98. https://doi.org/10.1089/cyber.2011.0151

Hall, J. A., Carter, J. D., \& Horgan, T. G. (2000). Gender differences in nonverbal communication of emotion. In A. Fischer (Ed.), Gender and emotion: social psychological perspectives (pp. 97-17). Cambridge University Press. https:// doi.org/10.1017/CBO9780511628191.006

Hess, U., Adams Jr, R., \& Kleck, R. (2005). Who may frown and who should smile? Dominance, affiliation, and the display of happiness and anger. Cognition $\mathcal{E}$ Emotion, 19(4), 515-536. https://doi.org/10.1080/02699930441000364

Heyman, A. (2020). Growing up female. In E. Arnold, A. Heyman, S. Meiselas, $\&$ C. Bouveresse (Eds.), Unretouched women: Eve Arnold, Abigail Heyman, Susan Meiselas. Femmes à l'oeuvre, femmes à l'épreuve de l'image (pp. 2-22). Actes Sud. (Original work published in 1974).

John, O. P., Naumann, L. P., \& Soto, C. J. (2008). Paradigm shift to the integrative Big Five trait taxonomy: history, measurement, and conceptual issues. In O. P. John, R. W. Robins, \& L. A. Pervin (Eds.). Handbook of personality psychology: theory and research ( ${ }^{\text {rd }} \mathrm{ed}$ ), (pp. 114-158). Guilford Press.

Kang, M. E. (1997). The portrayal of women's images in magazine advertisements: Goffman's gender analysis revisited. Sex Roles, 37(11-12), 979-996. 
LaFrance, M., \& Hecht, M. A. (1999). Option or obligation to smile: the effects of power and gender on facial expression. In P. Philippot, R. S. Feldman, $\&$ E. J. Coats (Eds.), The social context of nonverbal behavior (pp. 45-70). Cambridge University Press.

Looft, R. (2017): \#girlgaze: photography, fourth wave feminism, and social media advocacy. Continuum, 31(6), 892-902. https://doi.org/10.1080/10304312.201 7.1370539

Marín, F., \& Ganzabal, M. (2011). La mujer (in) visible: la construcción de la identidad femenina a través de la fotografía en El País y El Mundo. Enl@ce: Revista Venezolana de Información, Tecnología y Conocimiento, 8(3), 51-67.

Meiselas, S. (2020). Carnival strippers. In E. Arnold, A. Heyman, S. Meiselas, $\&$ C. Bouveresse (Eds.), Unretouched women: Eve Arnold, Abigail Heyman, Susan Meiselas. Femmes à l'oeuvre, femmes à l'épreuve de l'image (pp. 41-191). Actes Sud. (Original work published in 1976).

Mitchell, M. (1979). Recollections: ten women of photography. New York, NY: The Viking Press.

Morna, C. L. (Ed.). (2002). Gender in media training. A Southern African tool kit. DS Print Media.

Moss, J. (2014, November 1). As subtle as the pose. Retrieved September 25, 2020, from https://www.jennifermoss.com/

Moss, J. (2017, August 30). As subtle as the pose -3 years later. Retrieved September 25, 2020, from https://www.jennifermoss.com/

Mulvey, L. (1989). Visual and other pleasures. Palgrave Macmillan. https://doi. org/10.1007/978-1-349-19798-9

Muñoz-Muñoz, A. M., \& González-Moreno, M. B. (2014). La mujer como objeto (modelo) y sujeto (fotógrafa) en la fotografía. Arte, Individuo y Sociedad, 26(1), 39-54. https://doi.org/10.5209/rev_ARIS.2014.v26.n1.40581

Muñoz-Muñoz, A. M., \& González-Moreno, M. B. (2017). The presence of women photographers in the permanent collections of ten European museums. Curator: The Museum Journal, 60(2), 205-215. https://doi.org/10.1111/ cura.12198

Munro, E. (2013). Feminism: a fourth wave? Political Insight, 4 (2), 22-25. https:// doi.org/10.1111/2041-9066.12021

Newbury, D., Rizzo, L., \& Thomas, K. (2020). Women and photography in Africa. Routledge. https://doi.org/10.4324/9781003087410

Newhall, B. (2002). Historia de la fotografía. Barcelona: Gustavo Gili. 
Nochlin, L. (2018). Why have there been no great women artists? In L. Nochlin, Women, art, and power and other essays (2nd ed.) (pp. 1-36). Routledge. (Original work published in 1971). https://doi.org/10.4324/9780429502996-7 Otto, E., \& Rocco, V. (Eds.). (2011). The new woman international: representations in photography and film from the 1870s through the 1960s. University of Michigan Press. https://doi.org/10.3998/dcbooks.9475509.0001.001

Park, J., \& Ha, J. (2015). A study on female image of the third wave feminism in fashion photographs. Fashion \& Textile Research Journal, 17(1), 33-41. https:// doi.org/10.5805/SFTI.2015.17.1.33

Parrott, W. (2001). Emotions in social psychology: essential readings. Psychology Press.

Pérez Gauli, J. C. (2000). El cuerpo en venta: relación entre arte y publicidad. Cátedra.

Perkins, M. (2009). Poses for photographing women: a visual sourcebook for portrait photographers. Amherst Media.

Pultz, J. (1995). The body and the lens: photography 1839 to the present. Harry N. Abrams.

Raymond, C. (2017). Women photographers and feminist aesthetics. London: Routledge. https://doi.org/10.4324/9781315628912

Riches, H. (2014). 'Picture taking and picture making:' gender difference and the historiography of photography. In T. Sheehan (Ed.), Photography, history, difference (pp. 128-150). Dartmouth College Press.

Robinson, H. (1987). Visible female. Camden Press.

Rodgers, S., Kenix, L. J., \& Thorson, E. (2007). Stereotypical portrayals of emotionality in news photos. Mass Communication and Society, 10(1), 119-138. https://doi.org/10.1080/15205430709337007

Rojas, J. (2016). Photographing women: posing, lighting, and shooting techniques for portrait and fashion photography. Rocky Nook.

Rosenblum, N. (2015). A history of women photographers (3rd ed.). Abbeville Press Inc.

Rosler, M. (2004). Decoys and disruptions: selected writings 1975-2001. The MIT Press.

Rosler, M. (2012). Imágenes públicas: la función política de la imagen. FotoGGrafía. Ruggerone, L. (2006). The simulated (fictitious) body: the production of women's images in fashion photography. Poetics, 34(6), 354-369. https://doi. org/10.1016/j.poetic.2006.10.005 
Sattari, M., \& Mousavi, S. (2013). The role of gender in photographic works: Do men and women capture different photographs? International Journal of Women's Research, 2(2), 73-88.

Sebag-Montefiore, C. (2019). Women battling sexism in photography -a picture essay. The Guardian. Retrieved September 25, 2020, from https://www.theguardian.com/artanddesign/2019/mar/07/ women-battling-sexism-in-photography-a-picture-essay

Shaver, P., Schwartz, J., Kirson, D., \& O'Connor, C. (1987). Emotion knowledge: further exploration of a prototype approach. Journal of Personality and Social Psychology, 52 (6), 1061-1086. https://doi.org/10.1037/0022-3514.52.6.1061

Shields, S. A. (1987). Women, men, and the dilemma of emotion. In C. Hendrick (Ed.), Sex and gender (pp. 229-250). Sage.

Siegel, E. (2012). Photographing women: 1,000 poses. Peachpit Press.

Sontag, S. (1984). The double standard of aging. In M. Rainbolt and J. Fleetwood (Eds.). On the contrary: essays by men and women (pp. 99-112). State University of New York Press.

Sontag, S. (1999). A photograph is not an opinion. Or is it?. In A. Leibovitz, \& S. Sontag, Women: new portraits. New York: Random House. https://archive. nytimes.com/www.nytimes.com/library/photos/leibovitz/sontag-essay.html

Soobben, D. (2013). Photographic representation of women in the media: a case study of the post. Online Journal of Communication and Media Technologies, 3, 36-59.

Spence, J., \& Solomon, J. (1995). What can a woman do with a camera? Photography for women. Scarlett Press.

Sypeck, M. F., Gray, J. J., \& Ahrens, A. H. (2004). No longer just a pretty face: fashion magazines' depictions of ideal female beauty from 1959 to 1999. International Journal of Eating Disorders, 36(3), 342-347. https://doi. org/10.1002/eat.20039

Vitova, D. (2019, September 25). Why female photographers still mimic the male gaze. Retrieved March 10, 2021, from https://denisavitova.medium. com/why-female-photographers-still-mimic-the-male-gaze-b0a23f831773

Walsh, V.A. (1994). Unbounded women? Feminism, creativity and embodiment. In G. Jasser and M. Verloo, Feminisms in Europe: cultural and political practices. WISE. 
Whitley, C. T., \& Kalof, L. (2020). Women behind the shutter: exploring the place of women in elite environmental conservation photographer networks. Sociological Inquiry, 90(1), 147-171. https://doi.org/10.1111/soin.12318 Wolff, J. (1990). Feminine sentences: women, art and culture. Polity Press. Wolff, J. (1994). Resident alien: travel/memoir/gender. Polity Press.

Zafra, R. (2005). Netianas. N(h)hacer mujer en Internet. Madrid: Lengua de Trapo. Zafra, R. (2013). (h)adas. Mujeres que crean, programan, prosumen, teclean. Páginas de espuma. 